\title{
European luxury fashion brand advertising and marketing relating to nostalgia
}

\author{
Pelin Ok, Pompeu Fabra University, Department of Communication \\ pelin.ok01@estudiant.upf.edu
}

\begin{abstract}
This research seeks to examine how European luxury fashion brands use nostalgia in their advertising and marketing, and the benefits of using nostalgia by analyzing selected adverts from Vogue magazine. The research adopts Narrative Transportation Theory, aims to create a model which develops Van Laer, de Ruyter, Viscanti and Wentzels' (2014) "Extended Transportation-Imagery Model", and provides managerial implications. Qualitative content analysis of imagery was conducted to analyze 60 adverts of five luxury fashion brands between 2010-2016. This research offers a different product category to investigate for nostalgia literature: luxury fashion brands' advertising, a different cultural context: European luxury fashion brands, and examines luxury fashion brand characteristics within the adverts' narratives by semiotics discipline. Research identifies how nostalgia theme was used in these adverts, provides an understanding among the themes, and adverts' analysis in terms of luxury brand characteristics, narrative, and semiotics.
\end{abstract}

\section{Keywords}

Luxury fashion advertising, luxury brand characteristics, nostalgia, brand heritage, emotional branding, semiotics, narrative transportation theory

\section{Introduction}

The luxury market usually associated with exclusivity, and privilege which also provides a lifestyle to the customer, has been a growing sector over the years; even the global recession is not an obstacle for this market growth which overall exceeded $€ 1$ trillion in 2016 (Bain \& Company, 2016). Specifically, personal luxury fashion goods "ballooned to more than $€ 250$ billion in 2016, more than tripling over the past 20 years" (Bain \& Company, 2016, p. 5). Advertising of luxury fashion products has been crucial for luxury brands since it triggers this market growth by increasing brand awareness.

Fashion advertising in research has been discussed as not a separate section of advertising. However, it is different than regular advertising since fashion advertising includes, and uses specific techniques such as shock advertising (Andersson, Hedelin, Nilsson, \& Welander, 2004), and extraordinary and discrepant images (Phillips \& McQuarrie, 2011). Furthermore, luxury fashion advertising has content, and techniques, which are more concerned with the aesthetics, tonality, and narrative (Flueckiger, 2009). Common characteristics of luxury fashion brands are focused on a distinct brand identity: country of origin, heritage, and craftsmanship: role of the designer (Hines \& Bruce, 2007). Thus the difference in advertising approach of luxury fashion products occurs as a necessity for representing luxury products in an appropriate way by emphasizing exclusivity, rarity, and brand heritage characteristics (Okonkwo, 2007), however also focusing on the experience by the aim of selling the experience as a lifestyle (Hansen \& Wanke, 2011). While luxury advertising represents a lifestyle experience (Flueckiger, 2009), it also includes traditional, and cultural symbolic values (Freire, 2014) which are different, and specific to each luxury brand generated in advertising by using specific types of nostalgia: personal, historical (Stern, 1992a), or collective (Baker \& Kennedy, 1994) as a theme to persuade the customer via reminiscing his/her past. Nostalgia generated in advertising invokes familiar- 
ity (Van Laer et al., 2014), so that the audience empathizes with the content. This process leads to narrative transportation (Green \& Brock, 2000) of the audience which results in persuasion of the customer. This research seeks to answer the research question: How do European Luxury Fashion Brands use Nostalgia in their Advertising, and Marketing? Furthermore, the research aims to analyze how European luxury fashion brands use nostalgia as a theme in their advertising and marketing, and to analyze the benefits of using nostalgia theme in these adverts. The research has three objectives: firstly, to identify, and analyze various European luxury brands' advertising relating to nostalgia from Vogue magazine by a content analysis of imagery. Secondly to create a model which develops Van Laer et al.'s (2014) model which is an extended version of Narrative Transportation Imagery Model (Green \& Brock, 2002), and finally to provide managerial implications beyond the theory for advertisers, and marketers in terms of promoting nostalgia for luxury fashion advertising field.

Nostalgia research commonly focused on brand advertising of comfort food (Stern, 1992a). There is a gap in the nostalgia research in luxury fashion brands' advertising. Furthermore, the research aims to fill the gap in research suggestions: to explore other cultural contexts in terms of nostalgia and heritage, and to research a brand's heritage via content analysis in brand's advertising (Merchant \& Rose, 2013). Finally, the gap in the research of Kim, Lloyd, and Cervellon (2016) by analyzing the luxury brand characteristics in the advertising narratives in depth. Thus, this research has an original value since it fills the gap in literature by offering a different product category to investigate for nostalgia literature: luxury fashion brands' advertising, and from a different cultural context: European luxury fashion brands, and brands which target the European market. Furthermore, it aims to analyze luxury brand characteristics in further detail. The persuasion power of luxury fashion advertising is impressive, and different from regular advertising. That is why the rationale of conducting this research comes from the curiosity, and wish to analyze luxury fashion advertising relating to nostalgia in great detail which promotes, and triggers luxury fashion market's success. While the research aims to contribute to narrative transportation, and nostalgia literature in terms of advertising; it also draws managerial implications for marketers, and advertisers.

\section{Literature review}

\subsection{Luxury brand characteristics}

There are various core characteristics that a fashion brand must obtain to achieve an authentic luxury brand status. Okonkwo (2007, p. 105) describes these characteristics of luxury fashion brands' anatomy: "Innovative, creative, unique products; a heritage of craftsmanship; a distinct brand identity; high visibility; premium pricing; emotional appeal; a global reputation; consistent delivery of premium quality; exclusivity in goods production, and tightly controlled distribution". These characteristics are crucial for luxury fashion brands because they are the source of power, which provide a distinctive brand value for the brand, and emotional attachment for the customer. Another study relating to luxury fashion brands suggests the following six elements: "Excellent quality, high price, scarcity \& uniqueness, aesthetics \& polysensuality, ancestral heritage \& personal history, and superfluousness as key characteristics" (Dubois et al., 2001, cited in Hines \& Bruce, 2007, p. 131).

Country of origin "provides a national identity and attitude, associated with the brand" (Hines \& Bruce, 2007, p. 136). While this distinct national identity enables luxury brands to distinguish its identity among its rivals in the competitive luxury fashion market, it also increases brand awareness by attracting customer attention via familiarity of historical background. In addition "association with a country of origin that has an especially strong reputation as a source of excellence in the relevant product category" (Nueno \& Quelch, 1998, p. 63), is a sign of 
product quality. Another key characteristic: "Heritage of the brand and the history associated with its founder and its craftsmanship are built into the luxury brand" (Nueno \& Quelch, 1998, cited in Hines \& Bruce, 2007, p. 132). Particularly brand heritage refers to "a dimension of a brand's identity found in its track record, longevity, core values, use of symbols and particularly in the organizational belief that its history is important" (Urde et al., 2007, p. 4). Heritage, and craftsmanship do not only tell a story of a luxury brand's history, and guarantees longevity; but also points out the rarity, and exclusivity of the luxury products. Furthermore "the retention of heritage has the ability to create nostalgia and credibility for a brand, and is often correlated to the heritage of the country of origin" (Fionda \& Moore, 2009, p. 352). As a result of these crucial characteristics: "The luxury fashion brand becomes a lifestyle statement that permeates across other aspects than apparel" (Hines \& Bruce, 2007, p. 138). Furthermore, examining these characteristics in luxury fashion advertising narrative is a subject which requires further investigation because of the lack of research which combines these two areas.

\subsection{Luxury fashion advertising and marketing}

Even though research in advertising is very broad; research in fashion advertising is surprisingly narrow, and does not go beyond examining fashion imagery as an advertising type which mainly does not include text but includes extraordinary, and discrepant visuals (Phillips \& McQuarrie, 2011), has an aim to shock the audience with contents such as violence (Andersson et al., 2004), and is shaped through aesthetical concerns (Wallerstein, 1998). On the other hand, fashion imagery's social impact on women, and society has been researched in many perspectives. For instance, its impacts such as stereotyping idealized women (Stokrocki, 1988, cited in Phillips and McQuarrie, 2011), including thinness: Hunger, and unsmiling models associated with looks called heroin chic, and junkie look (Wallerstein, 1998), and representation of alternative sexualities
(Oswald, 2010) in fashion advertising in order to increase brand awareness, and target a broader audience.

However, luxury fashion brand advertising is more concerned with protecting the exclusivity of luxury products (Hines \& Bruce, 2007), aesthetics, and narrative (Flueckiger, 2009) of the advert, presenting the product in a story since it is not completely product focused, but mainly experience focused. Luxury adverts provide an abstractness (Hansen \& Wanke, 2011), and "mythical history" (Freire, 2014) of the luxury brand to the audience. The aim of selling the experience that a consumer might have by possessing the product rather than selling the product is crucial for a luxury fashion brand to achieve in their advertising approach.

"In the luxury domain in recent years, a certain type of advertisement has emerged that relies almost exclusively on the evocation of pure sensations" (Flueckiger, 2009, p. 196). Sensations provoke the audience to connect, and emphasize with the structure of the adverts. Such structure includes characters, product, plot, background, narrative, and music which lead to sensations as an outcome. Sensations are supported by "aesthetic features of style such as depth of field, diffusion, colour or light enhance the spectator's sensorial response" (Flueckiger, 2009, p. 196). Different than fashion advertising, luxury advertising is close to lifestyle advertising since the product, and its functional information are slightly mentioned.

On the other hand, Hansen, and Wanke (2011) argue the abstractness of luxury. Abstractness in their research refers to both the distance between the non-target audience, and the luxury product physically and psychologically. The distance between the product, and non-target audience occurs physically since "luxury is something inessential but conductive to pleasure and comfort or something expensive or hard to obtain" (Houghton Mifflin Company, 2000, cited in Hansen \& Wanke, 2011, p. 790). Thus luxury is only obtained by a limited audience, so that the regular customer feels both physically, and psychologically distanced from the world of 
luxury. The research also points out that "advertisers tend to use more abstract language when they describe their luxury products" (Hansen \& Wanke, 2011, p. 794). Since the product representation includes exclusivity, rarity, and a premium priced luxury product, the language also reflects these characteristics. While luxury advertising represents a lifestyle experience; it also includes traditional, and cultural values which are different, and specific to each luxury brand. "Luxury advertising is particularly image-dependent and vehicle their messages by interpreting representations and cultural symbols supposed to be known by the consumer" (Freire, 2014, p. 2668). Therefore, emphasizing, and representing roots, and historical values of these brands via advertising is crucial as a message. Adopting symbols within the adverts serves for this purpose.

\subsection{Semiotics}

Semiotics discipline enables this research to make solid comments on symbols, and cultural references located in the adverts. "Semiotics is a discipline that provides a structure for studying and analyzing how signs function within a particular environment" (Zakia \& Nadin, 1987, p. 5). Within a structure provided by semiotics, commentary on the signs gains value. According to the first semiotician Ferdinand de Saussure, signs had 2 elements in their structure: the signifier, and the signified. The signifier refers to the part of communication which carries the message, and the signified refers to which is communicated by the signifier (Hall, 2012). Fashion, and luxury fashion advertising frequently adopt semiotics since they use various symbols. Especially luxury fashion advertising which is more concerned with the narrative (Flueckiger, 2009), having an abstract representation (Hansen \& Wanke, 2011), representing brands' heritage, and mythical history (Freire, 2014).

\subsection{Narrative transportation}

Narrative in advertising is crucial for a luxury brand. It is not only a way to introduce their product but also a way to express the brand's identity, culture, heritage and life- style. "The power of narratives to change beliefs has never been doubted and has always been feared" (Green and Brock, 2000, p. 701). For a narrative to be powerful it is important to be able to transport the customer via empathy, and imagination. Narrative transportation theory constitutes the core of this research. Gerrig (1993) described transportation as an experience which a traveler (a metaphor for a reader), moves away from his world of origin by the experience of reading (travel), and this experience changes the traveler. Although Gerrig's research correctly identifies transportation, it fails to consider consequences, and components of this experience. However later Green and Brock (2000), further developed Gerrig's description of narrative transportation; defining it as a convergent mental process which might occur as a result of both fictional or non-fictional narratives. By focusing, transportation causes the reader to lose information of real world, and changes the reader's beliefs \& attitudes based on the narrative as consequences. Transportation makes the persuasion possible by reducing cognitive responding since it decreases counterarguments, negative thoughts, and makes the narrative look like a real life experience. Green and Brock (2000) established that transportation can be achieved by not only reading but also by listening, and viewing the content without a written material, while Escalas (2007) also argues that narrative transportation is possible via adverts if the adverts lead the customer to construct a narrative. Thus it explains the transportation power of fashion advertising which do not have texts.

Phillips and McQuarrie (2010) identify how the grotesque imagery can provide narrative transportation to the customer. The authors outline five modes of engagement which make persuasion possible. Even though their research connects fashion advertising to narrative transportation in grotesque imagery; it fails to consider luxury fashion brands' anatomy, and characteristics. Van Laer, De Ruyet, Visconti \& Wetzels (2014) provide an extended version of narrative transportation theory by developing a model about its anteced- 
ents, and consequences. Lastly, Kim et al. (2016) introduced luxury fashion branding to narrative transportation by researching narrative-transportation storylines in luxury brand advertising, focusing on themes which emerged from their interviewees' descriptions. However, further research in this area is necessary, since their research is limited to the themes they identified, and it does not offer an insight into the characteristics of luxury brands.

\subsection{Nostalgia}

Nostalgia used in advertising stimulates empathy with the customer via his past, and the customer experiences narrative transportation by the nostalgic advertising narrative. "Marketers can promote a brand's heritage by evoking the brand's history and/or a brand's origins through vicarious nostalgia based advertising" (Merchant \& Rose, 2013, p. 2624). Therefore; narrative transportation, brand heritage, and nostalgia theme in the adverts' narratives are linked together to persuade the customer.

Nostalgia is a yearning for yesterday (Davis, 1979). "A sentimental or bittersweet yearning for an experience, product, or service from the past" (Baker \&Kennedy, 1994, p. 169). Marketing, and advertising practices have started to include nostalgic themes increasingly in adverts since the 90's, therefore it is a relatively new application. Stern (1992a), identifies two types of nostalgia: personal, and historical. Personal nostalgia refers to idealizing "the personally remembered past" (Stern, 1992a, p. 16) while historical nostalgia refers to desire for returning to a time in the past before the audience was born. This is supported, and further developed by Baker and Kennedy (1994) who identified three types of nostalgia: real, stimulated, and collective. Real nostalgia is similar to personal nostalgia, its stimuli can evoke vivid memories since it is experience based. Stimulated nostalgia which is similar to historical nostalgia, refers to "yearning for the indirectly experienced past" (Baker \& Kennedy, 1994, p. 171). Finally, collective nostalgia which is a contribution to Stern's categorization, refers to "bittersweet yearning for the past which represents a culture, a generation, or a nation" (Baker \& Kennedy, 1994, p. 171). Even though nostalgia has been increasingly used as a theme in advertising and marketing; research of nostalgia's impacts on advertising is limited and relatively new. Havlena and Holak $(1991,1998)$ as well as Stern (1992a, 1992b) are the first authors who focused on nostalgia from a marketer, and advertiser's perspective rather than nostalgia research in psychology (Daniels, 1985), and sociology (Davis, 1979) fields.

Stern (1992a) identified benefits of using personal, and historical nostalgia in advertising separately since they are appropriate for certain products from different categories. The author claims that personal nostalgia is more useful for "cocooning or nesting products that are socially inconspicuous, but that provide the benefit of comfortability" (Stern, 1992a, p. 19). For instance: comfort food. Since these products speak to target audience's self-concept and is associated with their past: childhood, and home. However historical nostalgia suits representation of products which are more concerned with "status claims, and appeals to the consumer's ideal social self-concept” (Stern, 1992a, p. 19). Whereas Stern overlooked nostalgia's emotional impacts as a consequence of advertising, Havlena and Holak (1991) focused on benefits of nostalgia in advertising in terms of evoking positive emotions related to the customer's past. "Advertising for products may consciously evoke past associations and memories or create or recall positive affective responses" (Havlena \& Holak, 1991, p. 325). It is crucial for a nostalgia themed advertising to be able to filter negative thoughts that a costumer might possibly have about his/her past. The authors identified three possible cases which might occur: having neutral, negative or positive memories, and emotions about the past.

Merchant and Rose (2013), provide knowledge about the effects of historical nostalgia in advertising on brand heritage. Research reveals "the relationship between nostalgia proneness, and brand heritage highlights the importance of ef- 
fective advertisements in creating and enhancing brand heritage and deepening brand attachment" (Merchant \& Rose, 2013, p. 2624). Further research suggestions offer exploring other cultural contexts in terms of heritage, and nostalgia via content analysis (Merchant \& Rose, 2013). Research for nostalgia in advertising, and marketing is limited, and open to further investigation especially in different product areas, and brand categories. There is a gap in the nostalgia research in luxury fashion advertising which requires further research since heritage, and origins of luxury fashion brands are important characteristics; emphasizing brand heritage via advertising with nostalgia theme is crucial for a distinctive luxury brand identity. Therefore, consistent with the further research suggestions, this research aims to investigate European luxury fashion brand advertising relating to nostalgia, and how these brands use nostalgia theme in their marketing, and advertising.

\section{Methodology}

\subsection{Research question}

How do European Luxury Fashion Brands use Nostalgia in their Advertising, and Marketing?

\subsection{Philosophy}

The research adopts social constructivism philosophy which is a worldview where "individuals seek understanding of the world in which they live and work" (Creswell, 2014, p. 8). The reason for adopting social constructivism is that this philosophy enables the researcher to develop subjective, and multiple meanings from their experiences (Creswell, 2014).

\subsection{Theoretical framework}

Narrative Transportation Theory, constitutes the core of this research which provides a framework in order to understand, and investigate the narratives of the selected luxury fashion advertising relating to nostalgia. Accordingly, an extended version of the Transportation-Im- agery Model (Green \& Brock, 2002), established by Van Laer et al. (2014) was used as a model to follow since the advanced model provides specific antecedents, and consequences of narrative transportation in great detail from both the storyteller's, and story-receiver's perspective. The authors confirmed by their research that these antecedents affect, and increase narrative transportation. As consequences; audience's beliefs, attitudes, and purchase intentions change since narrative transportation increases affective responses, and decreases cognitive responses and critical thoughts (Van Laer et al., 2014). The research focuses on the storyteller components.

As seen in Figure 1, storyteller antecedents are identifiable characters, imaginable plot, and verisimilitude. "Identifiable characters affect narrative transportation because story receivers vicariously experience characters' beliefs and emotions, empathize with them, and become engrossed in the story" (Slater \& Rouner, 2002, cited in Van Laer et al., 2014, p.802). Imaginable plot makes narrative transportation possible since "stories resemble real-life experiences" (Green, 2006, cited in Van Laer et al., 2014, p. 802). Finally, verisimilitude refers to lifelikeness of the story which persuades audience that the story has a possibility to occur in real life. These storyteller components were examined as themes by a content analysis of imagery in luxury fashion adverts relating to nostalgia. Because identifiable characters whom the receiver can empathize with; imaginable plot which also proposes a lifestyle to the receiver; and verisimilitude are the themes which the receiver can empathize with by reminiscing his/her past, and can be found in nostalgia related advertising. Familiarity story receiver antecedent was also mentioned in this research, since it refers to "the degree to which a story receiver has prior knowledge about or personal experience with the story topic or genre" (Green, 2004, cited in Van Laer, 2014 , p. 803). Nostalgia provokes familiarity which leads to narrative transportation of the receiver. Provoked nostalgia in this case of familiarity might be personal, 
Figure 1: Extended Transportation-Imagery Model

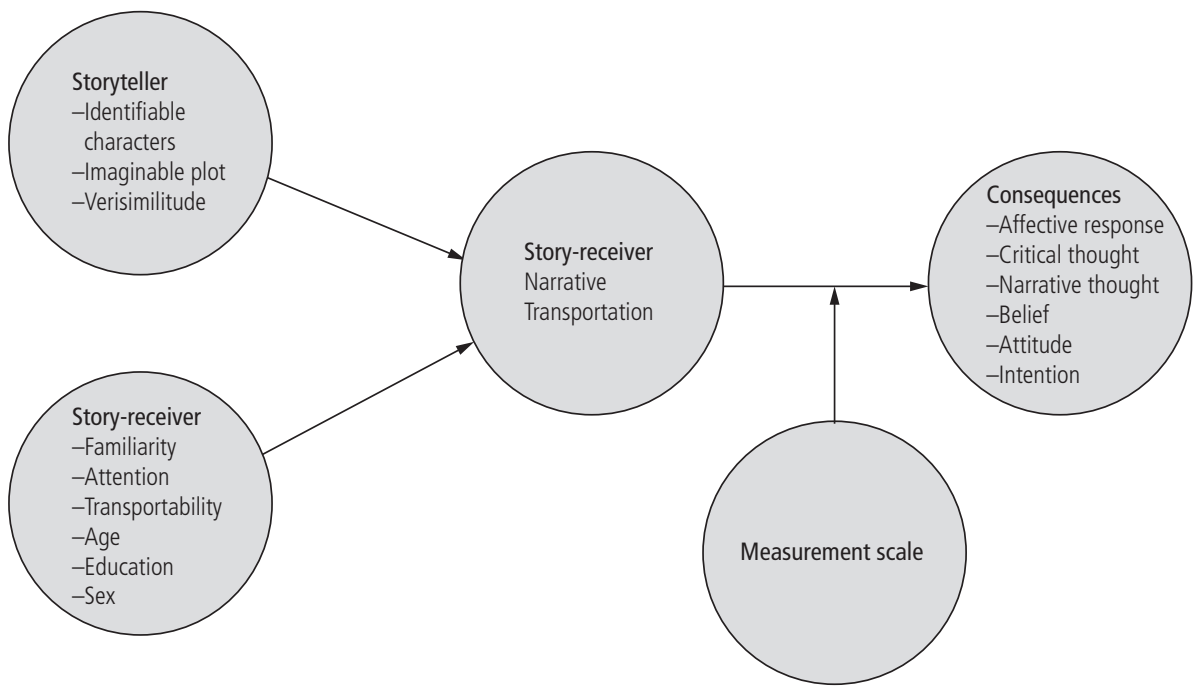

Adapted from Van Laer et al., 2014, p. 801

historical, or collective. Nostalgia type depends on the receiver's past experience, and triggers familiarity.

\subsection{Research method: content analysis}

Definition of content analysis has been changed over the history since the development process goes on. According to Holsti (1969), content analysis is a technique, which enables making inferences by identifying specific characters of messages objectively and systematically. Holsti (1965), groups 15 uses of content analysis into three main categories. The category: "To describe trends in communication content" is chosen. This category helps investigating the differences, and similarities among the findings; since content analysis is a useful technique for analyzing trends, and patterns within the text. The analysis was done in 2016, and to ensure cross-coder reliability; the results, and themes were crosschecked with a supervisor, and a group session activity in class.

\subsubsection{Semiotics}

Research adopts semiotics discipline to analyze 20 luxury fashion adverts with prominent symbols out of 60 selected ad- verts. A table for each advert was made which was inspired by Roland Barthes' (1964) Signifier and Signified Table and semiotics table of Freire (2014) in terms of structure.

Sample: For the qualitative content analysis of imagery, 60 print adverts from Italian Vogue between 2010-2016 were examined. The adverts of 5 luxury fashion brands targeting the European market were analyzed. Dolce \& Gabbana, Gucci, Louis Vuitton, Chanel, and Tommy Hilfiger brands were chosen; because their adverts are located in the first main pages of Vogue magazines, and they use nostalgia as a theme in their advertising the most since these brands have a strong brand heritage.

\section{Findings}

This research used content analysis of imagery to identify nostalgia in European luxury fashion brands' adverts. Firstly, descriptions of images were made; key themes, and words were formed as nodes in content analysis. Secondly, the software NVIVO was adopted to import the adverts, highlight, and code the adverts' descrip- 
tions. NVIVO is an advanced qualitative research software which enables the user to import, and analyze documents, images, and audios according to themes via coding (Qrinternational, 2015). The highlighted content from the descriptions were analyzed. The results were examined to understand nostalgia's use, and benefits in luxury fashion advertising. Vogue was used for this purpose since the magazine is published internationally, has a high circulation rate, and reputation for advertising various prestigious luxury brands over the history (Conde Nast, 2016). Vogue issues (72 issues) were examined to choose desired nostalgia related adverts. Luxury fashion adverts from selected issues between 2010-2016 were scanned, and imported. Two adverts per brand, and year. 60 adverts in total were examined to ensure parity. The reason for this timeframe is the increase observed in the use of nostalgia theme in luxury fashion advertising in this period. To discover the trends in the communication content, the descriptions of the scanned 60 adverts were coded according to the key themes and words. Text Search Query, and Word Frequency Query features were used by searching the selected words among the initial analysis data. Key themes, and words were selected again for the text search query option. Accordingly, the most frequently used key themes, and words related to nostalgia for each luxury fashion brand were found. Afterwards, a new version of major key themes, and words were revealed (See Table 1). The reason for narrowing down the number was to maintain the focus of this research: nostalgia.

\subsection{Analysis of adverts}

\subsubsection{Louis Vuitton adverts}

The main themes are travel, freedom, and escape. The models represent youth, natural beauty; their attitudes are fearless, and adventurous. However, the themes mentioned are represented by different symbols. In 2012-September advert (Table 2) (See Wwd.com, 2012) the symbol which represents travel, escape, and freedom is "an old train"; for 2014-April advert (Buro247.me, 2014): a safari car, and
Table 1: $\quad$ Final key themes and words

\begin{tabular}{|c|c|}
\hline $\begin{array}{l}\text { Final key themes } \\
\text { (Categories) }\end{array}$ & $\begin{array}{l}\text { Final key words: } \\
\text { for each key theme }\end{array}$ \\
\hline \multirow[t]{11}{*}{ Nostalgia } & Experience \\
\hline & Memories \\
\hline & Old \\
\hline & Vivid \\
\hline & Past \\
\hline & Birth \\
\hline & Vintage \\
\hline & Antiques \\
\hline & Bitter-sweet \\
\hline & Home-sick \\
\hline & Souvenir \\
\hline \multirow[t]{9}{*}{ Culture } & National Food \\
\hline & Music \\
\hline & Tradition \\
\hline & Origin \\
\hline & Home \\
\hline & Family \\
\hline & Dinner \\
\hline & Children \\
\hline & Movie reference \\
\hline \multirow[t]{6}{*}{ History } & Historical Buildings \\
\hline & Events \\
\hline & Ceremony \\
\hline & Childhood \\
\hline & Celebration \\
\hline & Historical \\
\hline \multirow[t]{4}{*}{ Heritage } & Personality \\
\hline & Longevity \\
\hline & Rarity \\
\hline & Craftsmanship \\
\hline \multirow[t]{8}{*}{ Lifestyle } & Travel \\
\hline & Escape \\
\hline & Youth \\
\hline & Holidays \\
\hline & Friends \\
\hline & Exclusivity \\
\hline & Freedom \\
\hline & College (University) \\
\hline \multirow[t]{3}{*}{ Fantasy } & Dreams \\
\hline & Exotic \\
\hline & Empathy \\
\hline \multirow[t]{4}{*}{ Aesthetics } & Symbols \\
\hline & Abstractness \\
\hline & Verisimilitude \\
\hline & (Life-Likeness) \\
\hline
\end{tabular}

a desert background. For 2012-December advert (Vogue.es, 2012) is a red hot air balloon, and Louvre Museum. Another common point is Louis Vuitton garments, bags, and suitcases located in these adverts. They represent heritage quality, craftsmanship, exclusivity, and brand history as luxury brand characteristics. Their symbolic meaning is that they provide a "support mechanism" for the models in their 
Table 2: $\quad$ LV advertisement 2012 september

\begin{tabular}{llll}
\hline $\begin{array}{l}\text { Personage/Object } \\
\text { (Icon/Signifier) }\end{array}$ & $\begin{array}{l}\text { Symbolic Meaning } \\
\text { (Signified) and Narrative }\end{array}$ & $\begin{array}{l}\text { Icon's contribution to luxury } \\
\text { brand characteristics }\end{array}$ & $\begin{array}{l}\text { Icon's contribution to } \\
\text { Nostalgia Literature }\end{array}$ \\
\hline Young Models & $\begin{array}{l}\text { Youth, beauty, fearless, } \\
\text { adventurous, freedom } \\
\text { Travel, holidays }\end{array}$ & Beauty, brand identity, rebellious & Youth, dreams, abstractness \\
Louis Vuitton Bags & $\begin{array}{l}\text { Authenticity, quality, innovation, } \\
\text { heritage, craftsmanship }\end{array}$ & $\begin{array}{l}\text { Traveling: Escaping from the } \\
\text { present to the past, home-sick }\end{array}$ \\
Old Train Background & nostalgic, timeless, historical & $\begin{array}{l}\text { Brand history, origins, roots, } \\
\text { lifestyle }\end{array}$ & Nostalgic, antiques, old \\
\hline
\end{tabular}

journey, and adventure. These symbols, and themes make the narrative stronger, and abstract. Furthermore, they contribute to nostalgia literature since they represent travel, which is an escape from the present life. The reason for that could be longing for, and missing one's past, and old memories. Nostalgic, vintage inspired garments, and suitcases; backgrounds such as an old train, and Louvre Museum (2012-December) in these adverts are other evidences for valuing the past. Such backgrounds, especially Louvre Museum are historical, and cultural references which represent the past, and origins of the luxury brand.

\subsubsection{Dolce \& Gabbana adverts}

The main themes are family, home, Italian tradition, and culture. The models represent natural beauty, traditional Italian women, and confidence. For the advert 2010-September (Porcelainista.net, 2014) the model (Madonna) represents a traditional Italian mother. She is in D\&G garments which have a traditional Italian style. They represent brand heritage, origin, and craftsmanship. The background is a traditional Italian family house which has nostalgic decoration inspired by D\&G's origin: Sicily. The baby is a symbol for childhood, innocence, and family that represents innovation as a luxury brand characteristic; family, future, and birth as nostalgia contributions. The representation of an Italian woman who is bonded to her family, and traditions becomes a powerful narrative, and represents a traditional Italian lifestyle which is nostalgic since it is different from today's Italian lifestyle. In the 2012-January advert (Table 3) (Yatzer.com, 2011), there is a crowded Italian family in front of a traditional Italian house as a background. It is a symbol for home, unity, and tradition. This symbol represents brand heritage, and history as luxury brand characteristics; unity, tradition, and home-sick memories as nostalgia literature contributions. The models are in traditionally designed lace clothes which represent brand heritage, origins: Sicily, and craftsmanship. There is a little boy who is a symbol for childhood, innocence, and freedom. It can be interpreted as innovation as a luxury brand characteristic; future, and freedom as contributions to nostalgia literature. The "white bow" which is on the little boy's suit is a symbol for the event: "first communion" It represents the respect for Italian traditions, and culture as contributions to nostalgia literature; brand's roots, and culture as luxury brand characteristics.

\subsubsection{Chanel adverts}

The common themes are nostalgia, history, and freedom. Adverts represent the $\mathrm{Pa}$ risian lifestyle from different time frames. Models represent youth, freedom, confidence, and iconic Parisian beauty and style. They are in iconic Chanel garments which emphasize brand identity, heritage, and craftsmanship. The advert: 2015-February (Conversationsabouther.net, 2014) takes place in front of the iconic Parisian café: Café de Flore. This café is a symbol for the classical Parisian café culture, and lifestyle. It represents brand history, and Parisian roots as luxury brand characteristics. The bag in the advert is a symbol for escaping, and traveling. It represents escaping from the present, going back home, and being home-sick as contributions to nostalgia literature. 
Table 3: $\quad$ D\&G advertisement 2012 january

\begin{tabular}{|c|c|c|c|}
\hline $\begin{array}{l}\text { Personage/Object } \\
\text { (Icon/Signifier) }\end{array}$ & $\begin{array}{l}\text { Symbolic Meaning } \\
\text { (Signified) and Narrative }\end{array}$ & $\begin{array}{l}\text { Icon's contribution } \\
\text { to luxury brand } \\
\text { characteristics }\end{array}$ & $\begin{array}{l}\text { Icon's contribution } \\
\text { to Nostalgia Literature }\end{array}$ \\
\hline Young Models & Youth, traditional beauty & $\begin{array}{l}\text { Youth, traditional beauty, } \\
\text { perfection }\end{array}$ & Youth, freedom, life-like \\
\hline Walk-on: Family & $\begin{array}{l}\text { Family, home, unity, tradition, } \\
\text { family gathering (for church) }\end{array}$ & $\begin{array}{l}\text { Brand history, heritage, } \\
\text { origins, roots }\end{array}$ & $\begin{array}{l}\text { Unity, home, home-sick, } \\
\text { tradition, memories }\end{array}$ \\
\hline Little Boy & $\begin{array}{l}\text { Childhood, innocence, } \\
\text { freedom, future }\end{array}$ & Innovation, future, freedom & Home, family, childhood, future \\
\hline White Bow (on little boy) & Church event: First Communion & $\begin{array}{l}\text { Respect for traditions, } \\
\text { and brand's roots: Italy }\end{array}$ & Tradition, culture, respect \\
\hline D\&G Garments & Traditional Italian style, origins & $\begin{array}{l}\text { Brand heritage, craftsmanship, } \\
\text { history, brand identity }\end{array}$ & Heritage, personality \\
\hline Italian House Background & $\begin{array}{l}\text { Family, home, unity, culture, } \\
\text { Italian tradition and lifestyle }\end{array}$ & $\begin{array}{l}\text { Brand history, origins, roots, } \\
\text { Italian lifestyle }\end{array}$ & $\begin{array}{l}\text { Tradition, culture, family, } \\
\text { home-sick, memories }\end{array}$ \\
\hline
\end{tabular}

Table 4: Chanel advertisement 2012 november

\begin{tabular}{|c|c|c|c|}
\hline $\begin{array}{l}\text { Personage/Object } \\
\text { (Icon/Signifier) }\end{array}$ & $\begin{array}{l}\text { Symbolic Meaning } \\
\text { (Signified) and Narrative }\end{array}$ & $\begin{array}{l}\text { Icon's contribution } \\
\text { to luxury brand } \\
\text { characteristics }\end{array}$ & $\begin{array}{l}\text { Icon's contribution to Nostalgia } \\
\text { Literature }\end{array}$ \\
\hline Young Model & $\begin{array}{l}\text { Youth, freedom, confidence, } \\
\text { fearless, beautiful, nostalgic }\end{array}$ & $\begin{array}{l}\text { Brand identity, beauty, } \\
\text { personality, rarity }\end{array}$ & Youth, dreams, abstractness, past \\
\hline $18^{\text {th }}$ Century Costume & $\begin{array}{l}\text { A reference to the } 18^{\text {th }} \text { Century } \\
\text { in Paris }\end{array}$ & $\begin{array}{l}\text { Authentic, longevity, brand } \\
\text { identity, brand origins, crafts- } \\
\text { manship, exclusivity }\end{array}$ & $\begin{array}{l}\text { Old, antiques, vintage, history, } \\
\text { Tradition }\end{array}$ \\
\hline Chanel Suit-Jacket & $\begin{array}{l}\text { Nostalgic, vintage, old, iconic, } \\
\text { antiques, reminds of Coco Chanel } \\
\text { the designer }\end{array}$ & $\begin{array}{l}\text { Tradition, craftsmanship, } \\
\text { heritage, longevity, brand identity, } \\
\text { rarity, personality }\end{array}$ & $\begin{array}{l}\text { Vintage, old, past, antiques, } \\
\text { heritage }\end{array}$ \\
\hline Palace Background & $\begin{array}{l}\text { Historical, reference, origins, } \\
\text { Parisian }\end{array}$ & $\begin{array}{l}\text { Brand origins, brand history, } \\
\text { heritage, roots, longevity }\end{array}$ & Historical, old, past, abstractness \\
\hline
\end{tabular}

Table 5: Gucci advertisement 2012 october

\begin{tabular}{|c|c|c|c|}
\hline $\begin{array}{l}\text { Personage/Object } \\
\text { (Icon/Signifier) }\end{array}$ & $\begin{array}{l}\text { Symbolic Meaning } \\
\text { (Signified) and Narrative }\end{array}$ & $\begin{array}{l}\text { Icon's contribution } \\
\text { to luxury brand } \\
\text { characteristics }\end{array}$ & $\begin{array}{l}\text { Icon's contribution to Nostalgia } \\
\text { Literature }\end{array}$ \\
\hline Young Model & Youth, natural beauty & $\begin{array}{l}\text { Brand identity, beauty, } \\
\text { personality }\end{array}$ & Youth, freedom, life-like \\
\hline Gucci Horsebit Loafers & $\begin{array}{l}\text { Recreation of Gucci Horsebit } \\
\text { Loafers from } 1953\end{array}$ & $\begin{array}{l}\text { Brand history, heritage, } \\
\text { craftsmanship }\end{array}$ & Vintage, Antiques, past \\
\hline Record Player and Records & $\begin{array}{l}\text { Vintage, antiques, old, } \\
\text { memories, souvenir }\end{array}$ & $\begin{array}{l}\text { Brand history, longevity, } \\
\text { personality }\end{array}$ & Vintage, Antiques, memories \\
\hline Home Background & Family, home, unity & Family lifestyle, comfort & $\begin{array}{l}\text { Family, going back home, } \\
\text { home-sick, memories }\end{array}$ \\
\hline
\end{tabular}

The advert: 2012-November (Table 4) (tatajazzblog.blogspot.com, 2012) has a palace background. The $18^{\text {th }}$ Century inspired costume of the model, and the background with antique possessions, represent the $18^{\text {th }}$ Century in Paris. This era is important for the narrative since it emphasizes the brand's origins. The back- ground, and costumes provide contributions to nostalgia literature since they are inspired from the past, and the French heritage historically.

\subsubsection{Gucci Adverts}

The advert 2015-July (Businessoffashion. com, 2015) has travel, and escape themes. 
The subway is a symbol for escaping from the present, and for freedom which are nostalgia contributions. The bag, and shoes are prominent; they represent brand heritage, and craftsmanship.

The advert: 2012-October (Table 5) (Pinkfishmedia.net, 2012) has home, and family themes. The model is in a family house which represents family, and unity. There are vintage records, and a record player in the background. They represent history, and memories as nostalgia contributions; longevity, and brand history as luxury characteristics. The model is in Gucci Horsebit Loafers which are recreations of the original shoes from 1953. They represent heritage, craftsmanship, and brand history.

\subsubsection{Tommy Hilfiger adverts}

The advert: 2011-December (Cdn.stylefrizz.com, 2011) has family, and holidays themes. The models in festive Tommy Hilfiger garments represent youth, and freedom. They have a carefree, and exclusive lifestyle. There is an old male model who is the father of the family. He represents guidance to the youth, the past, and unity as nostalgia contributions. There are also children who represent innocence, and future; innovation as luxury brand characteristics, and future and childhood as nostalgia contributions. There is a house background which is decorated for Christmas. It represents family, home, holidays, and unity as nostalgia contributions.

\section{Discussion}

\subsection{Representation of luxury brand characteristics}

Luxury brand characteristics: Heritage, craftsmanship, exclusivity, rarity, brand identity, brand origin, and longevity were highlighted in these adverts in the findings. By the strong narrative, and themes; brand origin, and heritage and craftsmanship characteristics were emphasized by representing the brand's country of origin as frequently seen in $D \& G$ adverts with the representation of Sicilian inspired lace clothes, and background decoration.
Furthermore, in Gucci, and Louis Vuitton adverts; craftsmanship, and product quality especially in terms of leather products were strongly emphasized within the narrative. Since leather products are the iconic products for both of the brands, and for Louis Vuitton leather travel-goods were its starting point-origin. Therefore, the research agrees with "association with a country of origin that has an especially strong reputation as a source of excellence in the relevant product category" (Nueno \& Quelch, 1998, p.63). It can be interpreted as the respect to the brand's country of origin. Heritage was the most important characteristic among them since it was frequently used to represent the brand's history. Exclusivity by representing an exclusive lifestyle, and rarity by providing rare luxury products were emphasized commonly as seen in Louis Vuitton, and Chanel adverts. Also quality of the product was strongly emphasized. Furthermore, youth was one of the most frequently used words to describe the models, and children. It can be interpreted as innovation: innovative designs of these brands.

Common points of research in luxury fashion characteristics were a distinct brand identity, country of origin, heritage and craftsmanship (Hines \& Bruce, 2007). Furthermore, as Fionda, and Moore (2009) identified heritage characteristic has the ability to create nostalgia, and credibility for the brand; and it is correlated to the brand's country of origin. It is also found in this research since heritage, nostalgia, and country of origin characteristics were inseparable in these adverts. According to Urde et al. (2007), brand heritage refers to core values, use of symbols, and brand history which is evident in the findings of this research suggesting that heritage characteristic was represented via symbols, and values which tell a story about brand history in these adverts. Finally, Kim et al. (2016) introduced luxury fashion branding to narrative transportation by focusing on themes which emerged from their interviews. Their research was limited to these themes. Thus this research fills this gap by analyzing the luxury brand characteristics in the advertising narratives in 
depth. According to analysis, luxury brand characteristics were emphasized via certain symbols embedded within the narrative of the advertising. The outcome of the advertising which is strengthened by various luxury brand characteristics provides a lifestyle to the customer. As a result, the brand becomes a lifestyle statement for the observer which makes the brand more than apparel (Hines \& Bruce, 2007).

\subsection{Luxury fashion advertising}

In the findings, the themes structured were nostalgia, culture, history, heritage, lifestyle, fantasy, and aesthetics. The lifestyle theme was frequently used in order to represent exclusive, and various lifestyles specific for each culture such as Parisian, and Italian cultures. Travel, holidays, escape, youth, and freedom were other sub themes used in the adverts along the lifestyle theme. This result is consistent with the suggestion of Flueckiger (2009) related to luxury fashion advertising being strong in narrative, and presenting the product in a story such as a lifestyle. These themes represent a free, adventurous, and exclusive lifestyle to the luxury customers. It can be interpreted as a longing for youth, and a carefree lifestyle since the luxury customers might have a busy lifestyle instead. Thus this research agrees with the reference on the luxury commercials depicting a form of travel which represents "experiences that might have occurred in the younger, more adventurous days of a now successful audience stuck in conventions" (Flueckiger, 2009, p. 206). Thus emotional connection to the advertising might lead to the thought of obtaining a free lifestyle by purchasing, and being a part of these brands. This theme is frequently used in Louis Vuitton adverts. Another key theme: Fantasy was used to represent dreams, and empathy that an observer might have. This theme combined with the lifestyle theme provides an exotic, abstract, and a dreamlike world to the audience. Due to these certain themes which represent abstractness, the research partially agrees with the statement of Hansen and Wanke (2011) which identifies luxury fashion advertising as an abstract type of advertising.
According to the findings, and analysis: Heritage theme as mentioned in luxury fashion brand characteristics represent the brand's identity, craftsmanship, longevity, and rarity. Heritage provides an emotional bond to the brand's culture, informs, and makes the observer be a part of the brand's history. That is why this theme was frequently linked to culture, and history themes in these adverts. Culture theme was used to represent customs, and traditions of the brand's country of origin as frequently seen in D\&G, and Chanel adverts. They emphasize the importance of family bounds, national tastes, and country of origin. This theme makes the observer feel familiar with the content due to his cultural background, advert's imaginable plot, and identifiable characters as family, so that the luxury brand does not look like a distant, and abstract aspect anymore. Furthermore, the theme history educates the observer in terms of the brand's history, or country of origin's history via using masterpieces as backgrounds such as The Louvre Museum, and Café de Flore in Paris in Louis Vuitton, and Chanel adverts. Knowing the history of the brand makes the observer feel connected to the brand on a personal level. The aesthetics theme includes the symbols, abstractness, and the verisimilitude (life-likeness) aspects. According to these themes, the adverts which included cultural, and nostalgia themes were more life-like which represent a lifestyle, and imaginable plot to the customer while the rest of the adverts had an abstract representation. Symbols were frequently used in these adverts to strengthen the narrative, and the themes mentioned; no matter if they were abstract, or life-like. According to the analysis, symbols have made the narrative more powerful, and provided cultural references. Being concerned with the aesthetics: Symbols, and narrative have made these adverts a form of art and presented emotional content to the customer which leads to more powerful emotional branding, and brand loyalty.

As Flueckiger (2009) suggests in luxury domain, the advertisement relies exclusively on the evocation of pure senses, 
aesthetics, and narrative. This research is in keeping with this as, according to the findings, aesthetic values such as symbols, representation of important themes strengthen the narrative, and also these aspects rely on evocation of senses. Furthermore, Hansen, and Wanke (2011) state that the luxury advertising is abstract due to the exclusivity of the products. This research partially agrees on this statement because of the certain symbols, and sometimes abstract narrative and themes such as fantasy, found in these adverts. However certain themes such as culture, and nostalgia provide an emotional connection to the observer due to having a warm, and welcoming representation which are imaginable, and life-like rather than abstract. Therefore, the research also strongly agrees with the statement of Flueckiger (2009) which suggests luxury advertising presents the product in a story such as a lifestyle. Finally, different from the researchers' opinions; this research states that certain themes: Nostalgia, and culture might bond the observer emotionally to the content; and the use of aesthetics makes the adverts a form of art instead of regular informative advertising.

\subsection{Nostalgia: how luxury fashion brands use nostalgia as a theme in their advertising}

According to the findings, nostalgia theme was frequently used in the selected adverts with the key words: past, vintage, antiques, bitter-sweet, memories, birth, experience, and home-sick. This major theme represents a longing for the past. Consistent with the adverts' analysis, nostalgia theme was frequently used to represent the brand's country of origin's traditional lifestyle, as can be seen in D\&G adverts emphasizing Sicily. The main emphasize was on traditional Italian women, family, and lifestyle. It can be interpreted as a respect from the brand to its root, a longing for family, traditions, and traditional Italian lifestyle. Similar to D\&G, Tommy Hilfiger adverts adopted nostalgia to represent the importance of family, unity, and home. One usually feels nostalgic when it is time to go back home for holidays, since it is the place where the childhood memories remain. However, in terms of Louis Vuitton adverts, the main theme was travel, and escape due to the brand's travel-goods origin. One desires to travel, or go on holidays when he/she needs a break from his present lifestyle. This can be also interpreted as nostalgia since the person wants to travel, and escape from his present lifestyle since the present lifestyle does not satisfy him. Different from the others; Chanel, and Gucci adverts adopted nostalgia to represent their brand heritage. Using nostalgia theme for emphasizing heritage is powerful for the narrative since it structures a story about the brand's roots, and history. For Chanel, representation of the country of origin's history via constructing narratives inspired from the $18^{\text {th }}$ Century France was a way to use Nostalgia. Gucci adverts focused on vintage Gucci products with nostalgic backgrounds which represented brand heritage, craftsmanship, and product quality.

When the observer experiences the nostalgia themed advertising, the advertising has an emotional impact on him/her via reminding of his past through the nostalgia theme since the plot is imaginable. The impact depends on the observer's past, memories, and the degree of familiarity he/she has with the nostalgia themed advertising content. Emotional bonding is a desired outcome for brands via using emotional branding paradigm. "Emotional branding focuses on brand meanings that interact with consumer lives and inspire their passion, lifestyle, memories, and experiences" (Thompson et al., 2006 cited in Akgün et al., 2013, p. 504). As seen in this research; the emotional content used for emphasizing luxury brand characteristics such as heritage, and themes as nostalgia, build an emotional bond between the brand, and observer which helps building brand attachment, and brand loyalty. "Emotional branding is a consumer-centric, relational, and story-driven approach to forging deep and enduring affective bonds between consumers and brands" (Roberts, 2004 cited in Thompson et al., 2006, p. 50). Due to being a story-driven approach; narratives, and the degree of 
empathy and familiarity used in the advertising content to emotionally affect the observer is crucial. Brands should focus on telling stories which inspire their costumers, and these stories should contain a true understanding of the observers' lifestyle, aims, and dreams (Thompson, 2006). Therefore, nostalgia theme also provides benefits for branding, and marketing via strengthening emotional branding.

Stern (1992a) identifies 2 nostalgia types: Personal nostalgia refers to idealizing the personally remembered past while historical nostalgia refers to desire for returning to a time in the past before the audience was born. In the analyzed adverts, both nostalgia types can be seen. Since some of them represent a closer time in the past as the 70's, 80's, 90's lifestyles; while some of them represent the $18^{\text {th }}$ Century, and before the observer was born. However, this research also agrees on the nostalgia definition of Baker \& Kennedy (1994), in which they identified 3 types of nostalgia. While real, and stimulated are similar to personal, and historical nostalgia; collective nostalgia refers to "a bittersweet yearning for the past which represents a culture, a generation, or a nation" (Baker \& Kennedy, 1994, p. 171). Because in the analyzed adverts, there are cultural references, and symbols which an observer from a certain cultural background, a generation, or a nation can only feel strongly familiar with.

Furthermore, this research agrees on the statement: "Marketers can promote a brand's heritage by evoking the brand's history and/or a brand's origins through vicarious nostalgia based advertising" (Merchant \& Rose, 2013, p. 2624). This statement was made for luxury brands; however according to the analysis, it is also acceptable for luxury fashion brands advertising since the use of heritage, and nostalgia together is evidenced; and nostalgia becomes a tool to inform the observer about the brand heritage. Thus this statement fills the gap in Merchant \& Rose's further research suggestions: to explore other cultural contexts in terms of vicarious (historical) nostalgia and heritage, and to research a brand's heritage in advertising via content analysis (Merchant \& Rose, 2013). Because this research examined the advertising of luxury fashion brands targeting the European market as a different cultural context via content analysis of imagery. On the other hand, Stern (1992a) suggests using nostalgia in advertising is more beneficial for nesting products, and comfort food. However, this research does not agree on Stern's generalization, since this research fills the gap in nostalgia literature in terms of luxury fashion brand category by showing that this field also adopts nostalgia for promoting brand heritage, and products by also using nostalgia as a theme for reminding of one's past, and childhood. Furthermore, Havlena, and Holak (1991) suggest that nostalgia evokes positive emotions, and filters negative thoughts related to the observer's past. This research agrees on this suggestion since the analyzed adverts projected a positive representation of the past, and the research states that nostalgia is beneficial to build an emotional bond between the observer, and brand which is possible by evoking positive memories about the past.

\subsection{Nostalgia, and narrative transportation}

Narrative is one of the most important elements of an advert especially for luxury fashion brands which aim to sell the experience. According to the analysis; strong key themes and words related to nostalgia, and symbols are the other core elements which strengthened the narrative. Using the theme nostalgia provides many benefits to the brand, and some of these benefits are the outcomes of narrative transportation.

As mentioned; Gerrig (1993), and Green \& Brock (2000) describe transportation as an experience which a traveler moves away from his world of origin by reading a realistic narrative, and this experience changes the traveler's beliefs, and attitudes due to losing information of the real world. It makes the persuasion possible by reducing cognitive responding, and increasing affective thoughts. Furthermore, Escalas (2007), and Phillip \& McQuarrie (2010) suggest that narrative 
Figure 2: Model: Benefits of Using Nostalgia in Luxury Fashion Advertising

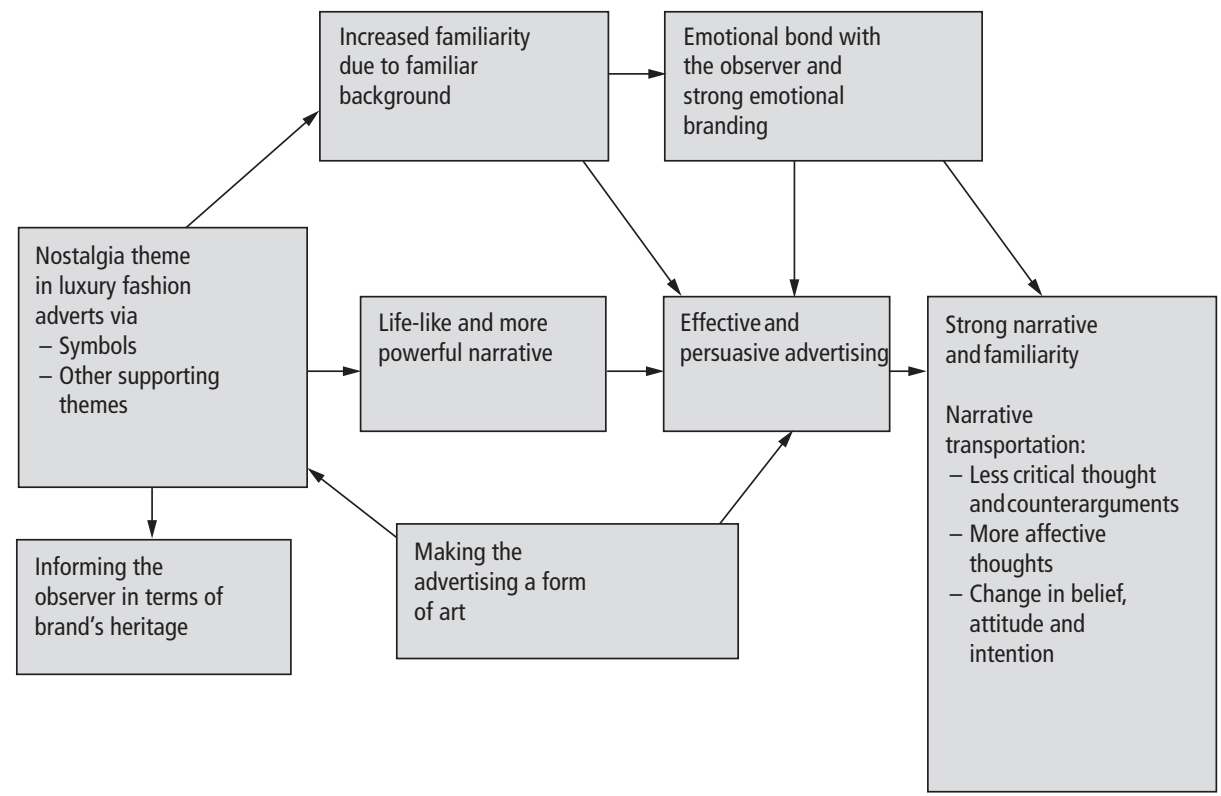

Own illustration

transportation is possible by observing also adverts since they provide necessary elements to construct a plot, and develop characters. This research was built on their suggestions, and is keeping up with their work as the adverts' analysis provide strong themes, symbols, and characters as necessary elements to construct a strong narrative. This research suggests that using nostalgia theme in luxury fashion advertising makes the narrative stronger. Because it provides a vivid - life-like (verisimilitude) story by using symbols, and strong themes as nostalgia. So that the observer feels familiar with the content of the advert which includes "identifiable characters, imaginable plot, and verisimilitude" due to his past memories, and experience which might happen because of personal, historical, or collective nostalgia depending on the person's past experience, cultural background, and age; consistent with Van Laer et al (2014) model.

Therefore, this research uses the "familiarity" element from the model of Van Laer et al (2014) to structure a new model which demonstrates benefits of using nostalgia in luxury fashion advertising, and the connection between nostalgia theme, and narrative transportation theory. The model (Figure 2) starts with: Adopting Nostalgia as a theme in luxury fashion advertising by also using symbols, and related themes. Then it further explains its benefits: Informing the observer about the brand's heritage, making the advertising a form of art due to the use of aesthetics, symbols and strong themes, building an emotional bond with the observer on a personal level via imaginable plot, and identifiable characters; strengthening emotional branding-brand loyalty, increasing familiarity of the observer to content due to familiar background related to nostalgia theme, and making the narrative life-like, and more powerful. In the end; the advert narratively transports the customer due to its effective narrative, and nostalgic content related to the observer's past experiences. Finally, according to narrative transportation theory, the observer's opinions, attitudes, and beliefs could tem- 
porarily change about the product due to less critical, and more affective thoughts. However, the aims of this research were to show how luxury fashion brands use nostalgia as a theme in their advertising, and to analyze benefits of using nostalgia rather than testing narrative transportation theory. Thus this research does not prove that narrative transportation happens at the end of this process, it assumes this last step: "familiarity" leads to narrative transportation based on the model of Van Laer et al. (2014).

\section{Conclusion}

This research aimed to identify how luxury fashion brands use nostalgia in their advertising, and marketing. Firstly, the research analyzed 5 luxury fashion brands' 60 adverts from Italian Vogue by a content analysis of imagery, and semiotics discipline. This research revealed the importance of luxury fashion brand characteristics for a luxury fashion brand in the adverts' narratives, identified that nostalgia theme was frequently used in the analyzed adverts, and explained the benefits of nostalgia. By filling the gap in the research of Stern (1992a), the research demonstrated that also this advertising field uses nostalgia frequently as a theme, not only nesting food. Research identified strong themes, and symbols' meanings embedded in the narrative connected to nostalgia theme; and structured a model based on Van Laer et al. model (2014).

\subsection{Recommendations}

Advertisers, and marketers can use nostalgia as a theme in their advertising to inform the customer in terms of the brand's heritage. Furthermore, using nostalgia with other sub-themes and symbols makes the advertising a form of art which should be the aim. Using this theme is especially suitable for luxury fashion advertising since it should be built along aesthetic values, and cultural symbols which are more concerned with making the advertising an art form. Nostalgia increases familiarity with the customer's background, builds an emotional bond between the brand and the customer, and strengthens emotional branding-brand loyalty. Thus it also provides benefits for branding, and marketing. Therefore, if decreasing the psychological distance between the luxury brand, and the customer is aimed; this theme can be used to increase emotional branding. Finally, nostalgia theme can be used to make the narrative more powerful, and life-like since it provides a familiar story to the observer. As demonstrated in Figure 2, the narrative supported by nostalgia theme makes the advertising more effective due to familiarity. Thus it has the ability to narratively transport the customer. Narrative transportation of the observer results in belief, attitude, and intention changes. Therefore, if it is used wisely by the industry; nostalgia is a crucial theme to make powerful adverts in luxury fashion advertising.

\subsection{Limitations and further research suggestions}

This research focused on European advertising perspective. Further research should examine other cultural contexts, and product areas of advertising relating to nostalgia.

\section{References}

Akgün, A., Koçoğlu, I. \& İmamoğlu, S. (2013). An emerging consumer experience: Emotional branding. Procedia-Social and Behavioral Sciences, 99(6), 503-508. doi:10.1016/j.sbspro.2013.10.519

Andersson, S., Hedelin, A., Nilsson, A., \& Welander, C. (2004). Violent advertising in fashion marketing. Journal of Fashion Marketing and Management: An International Journal, 8(1), 96-112. doi:10.1108/13612020410518727

Bain \& Company: D'Arpizio, C., Levato, F., Zito, D., \& De Montgolfier, J. (2016). Luxury Goods Worldwide Market Study. Bain \& Company, 1-27. Retrieved from http://www.bain.com/Images/BAIN_REPORT_Global_Luxury_2015.pdf [Accessed 31 Mar. 2015]. 
Baker, S. M., \& Kennedy, P. F. (1994). Death by nostalgia: A diagnosis of context-specific cases. Advances in Consumer Research, 21, 169-174.

Barthes, R. (1964). Elements of semiology. Paris: Jonathan Cape.

Buro247.me. (2014). First Look: Louis Vuitton Spring/Summer 2014 Campaign.

Retrieved from http://www.buro247.me/ fashion/news/louis-vuittoncampaign-spring-2014.html

Businessoffashion.com. (2015). Gucci 2015. Retrieved from https://images.businessoffashion.com/site/uploads/2015/07/ Gucci_1.jpg?auto=format\%2Ccompress\& crop=top \&fit $=$ crop $\& h=573 \& \mathrm{w}=1024$

Conversationsabouther.net. (2014). Gisele Bündchen Poses In Paris for Chanel Spring 2015 Campaign. Retrieved from http:// conversationsabouther.net/wp-content/ uploads/2014/12/chanel.jpg

Cdn.stylefrizz.com. (2011). Most Fashionable Christmas Party: Tommy Hilfiger Holiday 2011 Campaign. Retrieved from http:// cdn.stylefrizz.com/img/Tommy-HilfigerParty-Holiday-2011.jpg

Conde, Nast. (2016). Vogue I Conde Nast. [online] Conde Nast. Retrieved from http://www.condenast.com/brands/ vogue [Accessed 5 Apr. 2016].

Creswell, J. (2014). Research design: Qualitative, quantitative, and mixed methods approaches. 4th ed. Thousand Oaks, Calif.: Sage Publications.

Daniels, E. (1985). Nostalgia and hidden meaning. American Imago.

Davis, F. (1979). Yearning for yesterday. New York: Free Press.

Escalas, J. (2007). Self-referencing and persuasion: Narrative transportation versus analytical elaboration. Journal of Consumer Research, 33(4), 421-429. doi: $10.1086 / 510216$

Fionda, A., \& Moore, C. (2009). The anatomy of the luxury fashion brand. Journal of Brand Management, 16(5-6), 347-363. doi: $10.1057 / \mathrm{bm} .2008 .45$

Flueckiger, B. (2009). Lifestyle, aesthetics and narrative in luxury domain advertising. Popular Narrative Media, 2(2), 195-212. doi: $10.3828 /$ pnm.2009.6

Freire, N. (2014). When luxury advertising adds the identitary values of luxury: A semiotic analysis. Journal of Business Research, 67(12), 2666-2675. doi: 10.1016/j.jbusres.2014.04.004

Gerrig, R. (1993). Experiencing narrative worlds. New Haven: Yale University Press.

Green, M., \& Brock, T. (2002). In the mind's eye: Transportation-imagery model of narrative persuasion. 315-341.

Green, M., \& Brock, T. (2000). The role of transportation in the persuasiveness of public narratives. Journal of Personality and Social Psychology, 79(5), 701-721. doi: 10.1037//0022-3514.79.5.701

Hall, S. (2012). This means this, this means that. London: Laurence King Pub.

Hansen, J., \& Wanke, M. (2011). The abstractness of luxury. Journal of Economic Psychology, 32(5), 789-796. doi: 10.1016/j. joep.2011.05.005

Havlena, W., \& Holak, S. (1991). "The Good Old Days": Observations on nostalgia and its role in consumer behaviour. Advances in Consumer Research, 18, 323-329.

Havlena, W., \& Holak S. (1998). Feelings, fantasies, and memories: An examination of the emotional components of nostalgia. Journal of Business Research, 42(3), 217-226. doi: 10.1016/s0148-2963(97)00119-7

Hines, T., \& Bruce, M. (2007). Fashion marketing. Amsterdam; Boston: ButterworthHeinemann.

Holsti, O. (1965). Content analysis [by] Ole R. Holsti, with the collaboration of Joanne K. Loomba and Robert C. North. [Stanford, Calif.]: Stanford University.

Holsti, O. (1969). Content analysis for the social sciences and humanities. Reading, Mass.: Addison-Wesley Pub. Co.

Kim, J., Lloyd, S., \& Cervellon, M. (2016). Narrative-transportation storylines in luxury brand advertising: Motivating consumer engagement. Journal of Business Research, 69(1), 304-313. doi: 10.1016/j.jbusres.2015.08.02

Merchant, A., \& Rose, G. (2013). Effects of advertising-evoked vicarious nostalgia on brand heritage. Journal of Business Research, 66(12), 2619-2625. doi: 10.1016/j. jbusres.2012.05.021

Nueno, J., \& Quelch, J. (1998). The mass marketing of luxury. Business Horizons, 41(6), 61-68. 
Okonkwo, U. (2007). Luxury fashion branding. Basingstoke: Palgrave Macmillan.

Oswald, L. (2010). Marketing hedonics: Toward a psychoanalysis of advertising response. Journal of Marketing Communications, 16(3), 107-131. doi: $10.1080 / 13527260802503638$

Payload.cargocollective.com. (2012). Vogue.es. (2012). L'invitation au Voyage.Retrieved from https://www.vogue.es/moda/news/ galerias/l-invitation-au-voyage-de-louisvuitton/9092/image/667471

Phillips, B., \& McQuarrie, E. (2010). Narrative and persuasion in fashion advertising. Journal of Consumer Research, 37(3), 368-392. doi: 10.1086/653087

Phillips, B., \& McQuarrie, E. (2011). Contesting the social impact of marketing: A recharacterization of women's fashion advertising. Marketing Theory, 11(2), 99-126. doi: $10.1177 / 1470593111403215$

Pinkfishmedia.net. (2012). Retrieved from https://pinkfishmedia.net/forum/ proxy.php?image=http\%3A\%2F\%2F25. media.tumblr.com\%2Ftumblr_m97rc50vMw1r9e2vfo1_1280.jpg\&hash=95724la82e8e6e022e3508f22a4f9bcf

Porcelainista.net. (2014). Mamma Madonna. Retrieved from http://www.porcelainista. net/wp-content/uploads/2014/04/FW11_ Women_01.jpg

Qsrinternational.com. (2015). QSR - NVivo product range I QSR International. [online] Retrieved from http://www.qsinternational.com/product [Accessed 4 May 2016].

Stern, B. (1992a). Historical and personal nostalgia in advertising text: The fin de siecle effect. Journal of Advertising, 21(4), 11-22. doi: 10.1080/00913367.1992.10673382

Stern, B. (1992b). Nostalgia in advertising text: romancing the past. Advances in Consumer Research, 19, 388-389.

Stokrocki, M. (1988). Understanding popular culture: The uses and abuses of fashion advertising. Journal of Social Theory in Art Education, 69-76.

Tatajazzblog.blogspot.com. (2012). Chanel resort 2013 campaign with Cara and Saskia. Retrieved from http://1.bp.blogspot.com/-Q9jvpsEuhnE/UH8FeA9Y3ZI/
AAAAAAAAZJU/FNXXNPOSUeE/s640/ chanel1.jpg

Thompson, C., Rindfleisch, A., \& Arsel, Z. (2006). Emotional branding and the strategic value of the Doppelgänger brand image. Journal of Marketing, 70(1), 50-64. doi: 10.1509/jmkg.2006.70.1.50

Urde, M., Greyser, S., \& Balmer, J. (2007). Special issue papers: corporate brands with a heritage. Brand Management, 15, $1-17$.

Van Laer, T., de Ruyter, K., Visconti, L., \& Wetzels, M. (2014). The extended transportation-imagery model: A meta-analysis of the antecedents and consequences of consumers' narrative transportation. Journal of Consumer Research, 40(5), 797-817. doi: $10.1086 / 673383$

Wallerstein, K. (1998). Thinness and other refusals in contemporary fashion advertisements. Fashion Theory, 2(2), 129-150. doi: $10.2752 / 136270498779571149$

wwd.com. (2012). Louis Vuitton Uses TrainStation Set in Fall Ads. Retrieved from https://pmcwwd.files.wordpress. com/2012/06/lv-ad021.jpg?w=1024

Yatzer.com. (2011). Dolce \& Gabbana SS2012 Menswear Campaign Inspired by The Italian Cinema. Retrieved from https:// www.yatzer.com/sites/default/files/article_images/2805/Dolce-Gabbana-ss12yatzer-6.jpg

Zakia, R., \& Nadin, M. (1987). Semiotics, advertising and marketing, Journal of Consumer Marketing, 4(2), 5-12. doi: 10.1108/ eb008192a 